\title{
Carotenoid Content and Weight Gain of Caulerpa racemosa (Chlorophyta, Caulerpaceae) at Several Light Intensities
}

\author{
Rajuddin Syamsuddin ${ }^{1,2}$, Rustam $^{1,2}$, Abustang$^{2}$, Idil Fitra ${ }^{2}$ \\ ${ }^{1}$ Center of Excellence for Development and Utilization of Seaweed, Hasanuddin University (PUI-P2RL UNHAS), \\ Indonesia \\ ${ }^{2}$ Fisheries Department, Faculty of Marine Science and Fisheries, Hasanuddin University, Indonesia \\ Corresponding Author : Email : rajuddin_syamsuddin@yahoo.com
}

\begin{abstract}
An experiment was conducted done outdoors in the area of the Wet Laboratory of Faculty of Marine Science and Fisheries, HasanuddinUniversity to examine the influence of several light intensity ranges on carotenoid content and weight gain of the seaweed Caulerparacemosa. Filtered seawater and styrofoam boxes were the cultivation medium and container, used respectvely. Carotenoid content and the weight gain was analyzed in the Water Productivity and Quality Laboratory of FIKP, UNHAS. Carotenoid content was determined spectrometrically, the weight gain, carotenoids content and water quality parameters were statistically and descriptively analyzed, respectively. Low light intensity of $200-300$ lux was lower than the saturation point resultedlow weight gain due to photoinhibitionand decreased chlorophyll synthesis, greater respiration activity than photosynthesis.Light intensity range of $500-600$ lux was exceed the saturation point causecarotenoid damage, low weight gain due to photorespiration, decreased nitrate reductase activity, cell damage and death, reducephotosyntheisi and reduce cell size. Light intensity range of $400-500$ lux was the optimum and saturation point light intensityresultedhigh weight gain. The range of temperature, salinity, $\mathrm{pH}$, ammonium concentration, and magnesium water media during the study was suitable the growth of C.racemosa.
\end{abstract}

Keywords : Carotenoid, Caulerparacemosa, Low Light Intensity, Photoinhibition, Photorespiration, Weight Gain

\section{INTRODUCTION}

Currently, seaweeds are used worldwide formany different purposes. The human consumption of seaweedis common in Asian countries, mainly Japan,China,Korea,Vietnam, Indonesia and Taiwan (Dawes, 1981). Caulerpa racemosa is one of the seaweeds that is consumed directly as a vegetable by people in these countries. These species are known as valuable sources of protein, minerals, dietary fibers, vitamins, essential aminoacids, essential fatty acids and carotenoids.
Mass production of $C$. racemosa through cultivation has not been carried, and there is no method or standard cultivation technique has been found out yet. People still rely on extraction from nature for consumption of this species. Recent $C$. racemosa cultivation experiment in Indonesia is done by plugging it down to the sediment of the brackishwater fishpond.

This green alga are autotrophic organisms contain various pigments that absorb certain intensity of light energy to synthesize such kind of biocompounds. 
One of the such pigments is carotonoid. Carotenoid also act to protect chlorophyll from photo-oxidation. Algae exposed to light with different intensities will show differences in photosynthetic activity and chemical composition. Hence, light intensity is possible variable whose manipulation might enhance growth and carotenoid production of $C$. racemosa. Therefore some light intensity is tried to be exposed to tallus of $C$. racemosa outdoor and analyze their effect on growth and carotenoid content the species of algae.

The article presented here provides a brief and funfamental study of the influence of different low light intensity ranges on the weight gain and carotenoid content of $C$. racemosa.

\section{METHODS AND MATERIAL}

\section{STUDY SITE AND TIME}

The experiment was carried out for 2 months during the transition of dry season to rainy season (May July 2015) with a period of 45 days of seaweed growth at the open area, outside the Wet Laboratory, Faculty of Marine Science and Fisheries, Hasanuddin University (FIKP, UNHAS), Makassar, Indonesia

\section{SEAWEED SEED}

Seaweed used in this research was $C$. racemosa (Figure 1) obtained at the location of cultivator seaweed cultivation on the coast of Puntondo Village, Mangngara Bombang District, Takalar Regency, South Sulawesi Province, Indonesia. The seeds were then transported to the Wet Laboratory, Fisheries Department, Faculty of Marine and Fisheries, Hasanuddin University. Selected healthy seaweed seedlings were cleaned of sticky dirts.

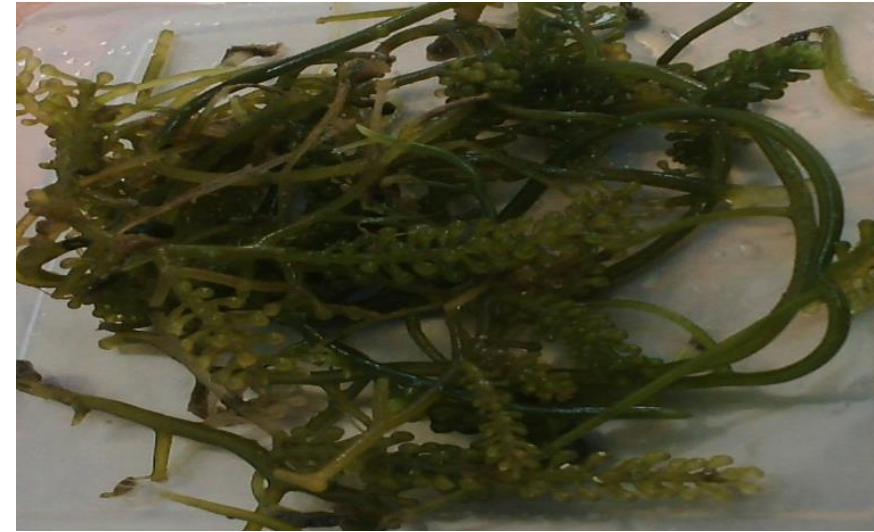

Figure 1. The Seaweed Caulerpa racemosa studied

\section{MEDIA AND CONTAINERS}

The physical and biological filtered water and a series of styrofoam boxes (Figure 2) were the cultivation medium and container, respectvely were used.

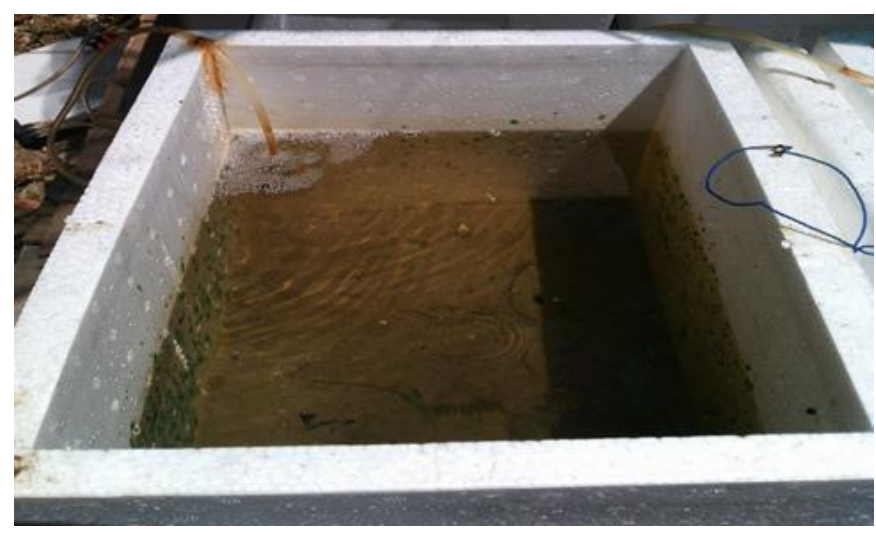

Figure 2. The container used to Culture C.racemosa

As a substrate for the growth of seaweed, the base of the research container is spread with $5 \mathrm{~cm}$ brackishwater pond soil sediment, then filled with filtered seawater as high as $30 \mathrm{~cm}$.. Previous to planting the seaweed, the water allowed to stand for 24 hours to precipitate suspended clay particles to get culture media that is free of clay particles causing the turbidity. 
SEAWEED CULTIVATION METHOD, TREATMENT AND EXPERIMENTAL DESIGN

The initial weight of $30 \mathrm{~g}$ of seedlings were placed in each container filled with water. The seaweed the seaweed is then exposed to direct sunlight with some light intensity being tested. Through setting the number (1 to 3 layered sheets) of the net and the distance above the top of the container the range of desired light intensities were obtained (Figure 3).

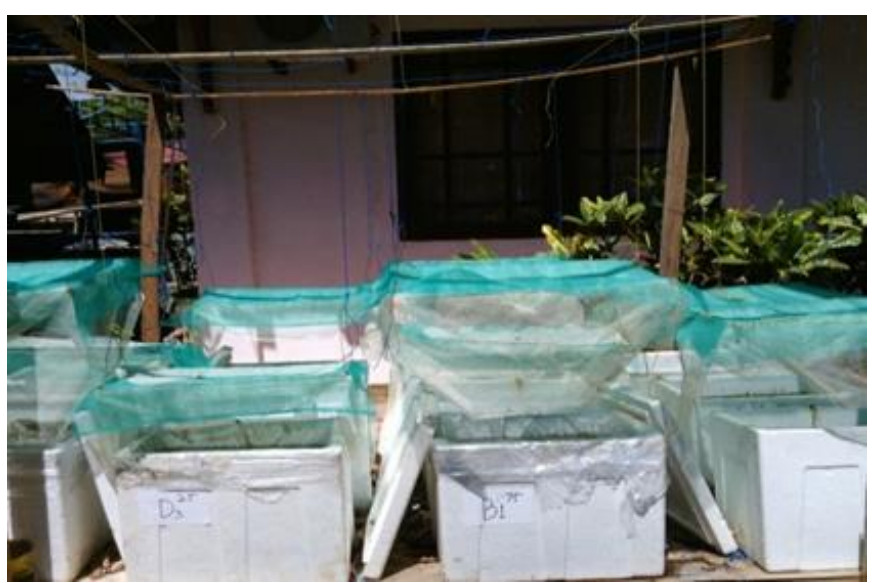

Figure 3. Top of the Containers were covered with net to obtain the light intensity range needed

The range of light intensities tested consisted of: 500 - 600 lux, B: 400 - 500 lux, 300 - 400 lux, and 200 300 lux, which were measured using Lux Meter. The determination and measurement of light those intensities were carried out twice a day, which is at $11.00 \mathrm{am}$, then set and measured again at 14.00 noon, when the intensity of sunlight and photosynthesis takes place maximally. All the treatments were designed with Complete Randomized Design (CRD) CRD with three replicates each. Each treatment and replication are placed randomly.

The range of light intensity tested is based on the findings that light intensity range of 380-720 lux is feasible for algae photosynthesis (Dring, 1971), that optimal light intensity for seaweed growth ranges from 333-1000 lux (Wood, 1989), and the maximum growth rate of seaweed is achieved at a light intensity of 600 lux (Mairth et.al., 1986). The standard irradiance of 400 - 500 lux had substantially higher amounts of carotenoid (Walsh et.al., 1997).

\section{WEIGHT GAIN MEASUREMEN}

Seaweed wet weight gain was measured at the end of the study using the following formula:

$\mathrm{W}=\mathrm{Wt}-\mathrm{W} 0 ; \mathrm{WW}=$ weight gain $(\mathrm{g}) ; \mathrm{Wt}=$ the final weight of seaweed (g)

$\mathrm{W} 0=$ the initial weight of seaweed $(\mathrm{g})$

\section{CAROTENOID CONTENT}

Carotenoid content was determined at the end of the study spectrophotometrically with a $480 \mathrm{~nm}$ wavelength (Kirk and Allen (1965, by Thirumaranand Anantharaman, 2009) in the Water Productiity and Quality Laboratory of the Fisheries Department, Faculty of Marine and Fisheries, Hasanuddin University and calculated by the following formula:

Carotenoid: $(\mu \mathrm{g} / \mathrm{g} . \mathrm{FW})=\Delta \mathrm{A} \cdot 480+(0,114 \mathrm{x} \Delta \mathrm{A} \cdot 663)-$

$(0,638 \mathrm{x} \Delta \mathrm{A} .645)$;

$\Delta \mathrm{A}=$ wave length at absorbant

\section{WATER QUALITY PARAMETERS}

Water quality parameters consisted of salinity, $\mathrm{pH}$, and temperature were monitored daily. Carbondioxide, ammonia, and magnesium, were analysedat the beginning, middle and end of the study at the Water Quality Laboratory, Department of Fisheries, Faculty of Marine and Fisheries, Hasanuddin University.

\section{DATA ANALYSIS}

The weight gain of C.racmosa was statistically analyzed using analysis of variance (ANOVA)(Steel 
and Torrie, 1993), while caratenoids content and water quality parameters were descriptively analyzed.

\section{RESULTS AND DISCUSSION}

\section{RESULTS}

There was a consistent increase in the carotenoid content of the seaweed C.racemosa when the light intensity increased, at light intensity of $200-300$ lux, $300-400$ lux, and $400-500$ lux, that was 2.98\%, 4.04, $4.48 \%$, respectively. However, lower carotenoid content $(3,62 \%)$ was recorded when the plant was exposed to further higher low light intensity (500 600 lux), some higher than at lowest light intensity (200-300 lux) wich results 2.98\% carotenoid content.

Analysis of variance (ANOVA) showed that the average weight gain of $C$. racemosa exposed to light intensity was not significantly different ( $\mathrm{p}>0.05$ ). However, the light intensity range of $400-500$ lux seems to be the optimal light intensity for this seaweed species because it provides a relatively high weight gain $(8-50 \pm 3.58 \mathrm{~g})$ compared to light with high intensity $(500-600$ lux with $4.40 \pm 0.98 \mathrm{~g}$ weight gain) and to lower light intensity (300 - 400 lux with $5,60 \pm 1,63$ g weight gain; 200 - 300 luxwith $4.40 \pm 0.98$ g weight gain) (Table 1). Havauxet.al. (2000 cited by Xuet.al. (2016) also noted a decrease in macro algae biomass at high light intensity.

Table 1. Average Weight Gain and Carotenoid Content at Different Light Intensity

\begin{tabular}{ccc}
\hline $\begin{array}{c}\text { Light Intensity Range Carotenoid Content Average Weight Gain } \\
(\text { lux })\end{array}$ & $(\%)$ & $(\mathrm{g})$ \\
\hline $500-600$ & 3.62 & $4.40 \pm 0.98$ \\
$400-500$ & 4.48 & $8.50 \pm 3.58$ \\
$300-400$ & 4.04 & $5.60 \pm 1,63$ \\
$200-300$ & 2.98 & $4.08 \pm 4.55$ \\
\hline
\end{tabular}

Water temperature recorded at the range of 27 to $31^{\circ} \mathrm{C}$, salinity 30 to $35 \mathrm{ppt}, \mathrm{pH} 7$ to 8.1 , magnesium concentration was 4804.8 - 5505.5 ppm, ammonium
$0.003-0.016 \mathrm{ppm}$. Free carbon dioxide concentration was undetectable.

\section{DISCUSSION}

Light intensity affects the chemical composition, pigment content (including carotenoids) and photosynthetic activity of algae. Therefore light intensity affects the growth and composition of algal biomass (Wahidin et al., 2013). The increase in biomass and carotenoid content depends on the intensity of light (Gross, 1991). his change in carotenoid content in seaweed is a physiological response (photoaclimation) triggered by variations in light intensity (Anderson, 1986). Carotenoid content changes with light intensity, and tends to vary according to species in the same way (Goericke and Montoya 1988; Schulteret al., 2000 cited by Grant, 2011) as a mechanism for protecting tissue cells active in photosynthesis from damage caused by the quality and quantity of light that cannot be tolerated.

This photoprotecting pigment concentration increases in order to prevent photoinhibition of the plant tissues ( Grant, 2011) which was occurred both at low light intensity (200-300 lux) and high light intensity (500-600 lux). Under low ligh tconditions, carotenoid on the one hand serve as accessory pigments, harvesting light energy and transferring it to chlorophyll a molecules), while underhigh light conditions, they protect chlorophyll $a$ of C.racemosa from photo-oxidation (SiefermannHarms,1980). On the other, when the cells of plant exposed to very high ligh intensity (500 - 600 lux), damage or drop of photosynthetic receptor (carotenoid in addition to chlorophyll) was occurred.

According to Dawes (1981) algae can grow well in the presence of sufficient light. In addition to chlorophyll and several other photosynthetic pigments, carotenoids are supporting pigments in seaweed in 
capturing light energy at certain wavelengths that cannot be captured by chlorophyll. The light is then transferred to chlorophyll for photosynthesis (Zigmantas et. Al., 2002). Photographs of pigment adaptation to light sources lead to changes in growth in addition to cell composition (including the carotenoid pigment content (Rüdigerand LópezFigueroa, 1992). According to Geider (2006), the amount and quality of light is very influential in photosynthesis (Geider, 2006; Gammanpila et. Al., 2015), so that it influences cell division and cell enlargement that causes growth.

The condition of light intensity determines biomass productivity and cell growth (Kumar et.al, 2015) because the amount of light received and stored by seaweed has a direct effect on carbon fixation capacity (Kumar et.al, 2015). The solar energy captured then converted into chemical energy (ATP and NADPH) in the process of photosynthesis (Taiz and Zeiger, 2002). Therefore the growth and metabolism of these algae depends on the efficiency of the conversion of light into chemical energy (Richmond, 2004). Biomass is higher at high light intensities compared to biomass at low light intensity (Iwamoto et. Al., 1955; Gammanpila et. Al., 2015). Increasing the weight of C.racemosa seaweed from the light intensity range of $200-300$ lux to $300-400$ lux then maximum at optimal light intensity 400 500 lux.

Light provides energy to transfer electrons from water to NADP and forms NADPH (nicotinamideadeninedinucleotidephosphate) and produces ATP (adeninetriphosphate) (Salisbury and Rose, 1969). Low light intensities ranging from 200 300 lux are beyond the saturation point (Sorokin and Krauss, 1958 cited by YingYang, 2013) and unfavorable intensities (Van Oorschoot 1955) results in photoinhibition, thus limiting biomass accumulation (Sorokin and Krauss, 1958 quoted by YingYang), 2013). At low light intensities, photosynthesis occurs slowly because only a small amount of ATP and NADPH is produced by lightdependent reactions. In addition, a decrease in light intensity results in a greater increase in respiratory activity than photosynthesis (Iwamoto et al. 1955), which can reduce its weight (Gardner, 1995). The reduction in biomass is also caused by a decrease in chlorophyll synthesis (Pisal and Catfish, 2004; Kumar et al. 2011; Xu et al. 2016).

With increasing light intensity, more ATP and $\mathrm{NADPH}$ are made, thus increasing the rate of photosynthesis. However, when the light intensity is above the saturation point for this algae species, photorespiration occurs, which occurs at the same time as photosynthesis (Salisbury and Rose, 1969), where much oxygen is built (oxygen production exceeds $\mathrm{CO}_{2}$ production during photosynthetic light reactions), so the amount of oxygen exceeds the amount of carbon dioxide produced. Thus, the RuBisCO enzyme oxidizes RuBP (RuBP receives oxygen instead of fixing $\mathrm{CO}_{2}$ ) during photosynthesis, causing some of the energy produced by photosynthesis to be in vain (ATP is only spent). The range of light intensity 500 - 600 lux is classified as a saturation point that causes light inhibition (Van Oorschoot 1955; Pulz, 2001), which reduces plant photosynthesis capacity (Iwamoto et.al., 1955; Stigum, 2002), which inhibits growth rates due to damage cells, reduce cell size (diameter) and cause cell death (Loera-Quezada et al., 2011). The barriers of vegetative growth (thallus) from seaweed can also be caused by a decrease in the activity of nitrate reductase (an enzyme that reduces nitrate to ammonium) at high light intensities (Peni et al, 2003) so that ammonium which is a form of nitrogen directly enters the protein metabolism process (Syrett , 1962) concentration is limited in supporting the 
growth of C.racemosa. The range of light intensity 400 - 500 lux is the optimal light intensity (saturation point) which is a remarkable effect for biomass production and storage. This optimal level of light intensity expresses its photosynthetic ability to fully maximize photographic results in high biomass content (Gammanpilaet.al., 2015). So the light saturation point, the light conditions for maximum biomass storage fall within the range of light intensity 400 - 500 lux.

The recorded water temperature range is considered to support Growth of C.racemosa. This is consistent with the opinion of Afrianto and Liviawaty (1993), which states that seaweed grows and develops well below the water temperature range of $26-33^{\circ} \mathrm{C}$. The range of salinity is suitable for the growth of C.racemosa (Carruterset. Al., 1993; Azizah, 2006). The $\mathrm{pH}$ of the water medium is within optimal limits to support the growth of C.racemosa. This was confirmed by Setiajiet al. (2012), that the $\mathrm{pH}$ of sea water with a range of 8.0 to 8.7 is feasible for the growth of C.racemosa. The range of magnesium concentration was optimal for the growth of $C$. racemosa in the range of 135.11-1652-0.42 ppm (Anonim, 2006). The function of magnesium is for cell metabolism and phosphate energy transfer. The ammonium concentration is in the high category. According to Andarias (1992), good ammonium levels for the growth of marine algae are in the range of 0.01-0.03 ppm. The undetectable concentration of carbon dioxide does not mean that there is no carbon source for photosynthesis. Seawater with high carbonate content becomes a source of carbon dioxide, although the concentration is directly used in photosynthesis and the rest in water is very low and cannot be detected by the analytical method used.

\section{IV.CONCLUSION}

Carotenoid content of C.racemosa increases to prevent photoinhibition the plant tissues both at low light intensity (200-300 lux) and high light intensity (500-600 lux). When plant exposed to very high light intensity of $500-600$ lux, damage or drop of carotenoid was occurred.

Low light intensity ranges of $200-300$ lux was beyond the saturation point resulting in photoinhibition and decreased chlorophyll synthesis so that the respiration rate increases and exceedsphotosyn thesis, , ultimately reduced the biomass. Light intensity range of $500-600$ lux was above the saturation point which causes photorespiration and light inhibition, reduce photosynthetic capacity of the plant, cell damage, penurunanaktifitasnitrat reduktase, reduce cell size, and finally inhibiting the growth rate and causes cell death. Light intensity range of $400-$ 500 lux was the optimum light intensity express the photosynthetic ability to fully utilize the photoenergy, favourable effect for biomass production resulting in high weight gain. The range of temperature, salinity, $\mathrm{pH}$, ammonium concentration, and magnesium water media were considered to support the growth of C. racemosa. Seawater media with high carbonate content is a source of carbon dioxide that is utilized in the photosynthesis.

\section{ACKNOWLEDGEMENT}

The authors gratefully thank the support of the Ministry of Research, Technology and Higher Education of the Republic of Indonesia and to the Rector of Hasanuddin University, Makassar, 
Indonesia who gave the author the appropriate appreciation in compiling this scientific work. This article is published because of the assistance of the Director and all UNHAS CEDUS managers. Thanks, were expressed To Mr. Yulius for his help in the research.

\section{REFERENCES}

[1]. Andarias, I. 1992. Pengaruh takaran urea dan TSP terhadap produksi bobot kering klekap. Bulletin ilmu perikanan dan peternakan. Universitas Hasanuddin Makassar.

[2]. Anderson J.M. 1986. Photoregulation of the composition, function, and structure of thylakoid membranes. Annual Review of Plant Physiology 37: 93-136

[3]. Afrianto, E and E. Liviawaty. 1993. Budidaya Laut dan Cara Pengolahannya. Bharata. Jakarta.

[4]. Azizah, R.T.N., 2006. Percobaan Berbagai Macam Metode Budidaya Latoh (C.racemosa) sebagai Upaya Menunjang Komunitas Produksi. Jurusan Ilmu Kelautan, Fakultas Perikanan dan Ilmu Kelautan Universitas Diponegoro, Kampus Temalang Semarang, Indonesia.

[5]. Carruthers T.J.B., D.I Walker and J.M. Huisman . 1993. Culture studies on two morphological types of Caulerpa (Chlorophyta) from Perth, Western Australia, with a description of a new species. Botanica Marina 36: 589-596.

[6]. Dawes, C. J. 1981. Marine Botany. John Wiley. And Sons University of South Florida. New York. 268 pp.

[7]. Donatas Z., D., R. G. Hiller, V. Sundström, and T. Polívka. 2002. Carotenoid to chlorophyll energy transfer in the peridinin-chlorophyll-aprotein complex involves an intramolecular charge transfer state. Proceeding of the National Academy of Science of USA.; https://doi.org/10.1073/pnas.262537599
[8]. Dring, M.J. 1971. Light Quality and Photimorphogenesis of Algae in Marine Environment. 14th European Marine Biology Symposium. Cambridge University Press, pp. 375-392.

[9]. Fleurence, J. 1999. Seaweed Proteins; biochemical, nutritional aspects and potential uses.Trend in Food Science and Technology, 10; $25-28$.

[10]. Gammanpila, A.M., C.P. Rupasinghe, S. A Subasinghe 2015. Light Intensity and Photoperiod Effect on Growth and Lipid Accumulation of Microalgae Chlorella vulgaris and Nannochloropsis $\mathrm{Sp}$ for Biodiesel Production.

Proceedingsof12thISERDInternationalConferen ce,Tokyo,Japan,26thSept.2015,ISBN:978-9385832-00-0

[11]. Gardner, F.P. 1995. Fisiologi Tanaman Budidaya. Penerjemah: Susilo, H. Jakarta: UI Press.

[12]. Geider, W. 2006. Fotosintesis Pada Alga dan Bakteri. Wikipedia.Indonesia. www.Google.com (24 January 2011. 18.40)

[13]. Goericke, R. and J.P. Montoya. 1998. Estimating the contribution of microalgal taxa to hlorophyll a in the field - variations of pigment ratios under nutrient-and-lightlimited growth. Marine EcologyProgress Series, $169,97-112$.

[14]. Grant, C. 2011. Light Intensity Influence on Algal Pigments, Protein and Carbohydrates; Implications for Pigment-Based Chemotaxonomy. A Dissertation. Faculty of The Charles E. Schmidt College ofScience

[15]. Havaux, M., J.P. Bonfils, C. Lütz, K.K. Niyogi. 2000. Photodamage of the photosynthetic apparatus and its dependence on the leaf developmental stage in the npq1 Arabidopsis mutant deficient in the xanthophyll cycle 
enzyme violaxanthin de-epoxidase. Plant Physiol. 2000;124:273-284.

[16]. Iwamoto, H., G. Yonekawa and T. Asai. 1955 Fat Synthesis in Unicellular Algae. Part I. Culture Conditions for Fat Accumulation in Chlorella Cells. [Bull. Agr. Chem. Soc. Vol. 19, No. 4, 1955] pp.241-246

[17]. Kabinawa, I. N. K.. 2006. Spirulina Ganggang Penggempur Aneka Penyakit. AgroMedia Pustaka. Jakarta. Hal 10.

[18]. Kumar, M., J. Kulshreshtha and G. P. Singh. 2011 Growth and biopigment accumulation of Cyanobacterium Spirulinaplatensis at different light intensities and temperature. Braz. J. Microbiol. 2011:42(3):1128-1135

[19]. Loera-Quezada, MM, G. Angeles, E.J. Qlguín. 2011. Effect of irradiance on the cell density, size and lipid accumulation of Neochlorisoleoabundans. $\operatorname{Rev}$ LatinoamBiotechnolAmb Algal 2: 81-92

[20]. Mairh, O.P., U. Soe-Htun, and M.Ohno. 1986. Culture of Eucheuma striatum (Rodophyta, Solieraceae) in sub tropical of Shikoku,japan. Botanica Marina 29: 185-191.

[21]. Marinho-Soriano, E., P.C. Fonseca, M.A.A.Carnerio, and W.S.C. Moreira. 2006. Seasonal Variation in the Chemical Composition . of Two Tropical Seaweeds. Bioresource Tech., 97:2402 - 2406

[22]. Peni, D.K. Solichatun, dan E. Anggarwulan. 2003. Pertumbuhan, KadarKlorofil Karotenoid, Saponin, AktivitasNitratReduktaseAntinganting (GA3)yang(Acalyphindica L.) pada Konsentrasi Asam Giberelat Berbeda.Jurusan Biologi,FMIPA. Universitas Sebelas Maret Surakarta. 57126.

[23]. Pisal, D.S and S. S. Lele. 2004. Carotenoid production from microalga,Dunaliellasalina. Indian Journal of Biotechnology, Vol 4, October 2005, pp 476-483
[24]. Richmond, A. 2004. Handbook of microalgal culture: Biotechnology and applied phycology. Blackwell Science Ltd., Oxford, UK

[25]. Rudiger W, and F. López - Figueroa. 1992. Photoreceptors in algae. Photochemistry and Photobiology 55: 949-954

[26]. Salisbury, F.K. and C.Ross. 1969. Plant Physiology. Wadsworth Publ.Co.Inc. Belmon, California. $764 \mathrm{p}$.

[27]. Schulter, L., F.Mohlenberg, H. Havskum, and S. Larsen. 2000. The use of phytoplankton pigments for identifying and quantifying phytoplankton groups in coastal areas: testing the influence of light and nutrients on pigment/chlorophyll a ratios. Marine Ecology Progress Series, 192, 49-63.

[28]. Siefermann-Harms, D. 1980, The role of carotenoids in chioroplasts of higher plants, In Biogenesis and Function of Plant Lipids (P. Mazliak, P. Benveniste, C, Costes, and R. Douce, eds), pp. 331-340, Elsevier/NorthHolland Biomedical Press, ISBN 0-86689-01-6

[29]. Steel, R.G.D., danJ.H,Torrie, 1993. Prinsip dan Prosedur Statistika, Suatu Pendekatan Biometrik. Terjemahan Bambang Sumantri, GramediaPustakaUtama, Jakarta.

[30]. Stigum, V.M. 2012. The effect of light and temperatureon lipid production in microalgae. Master thesis. Deparmentof Biology. Program for Marine Biology and Limnology Universitetet, Oslo. 58p.

[31]. Syrett, P.J. 1962. Nitrogen assimilation. In: Lewin, R.A. (Ed.). 1962. Physiology and biochemistry of algae. Acad. Press. New York. Pp. 171-188

[32]. Taiz, L., and E. Zeiger. 2002. Plant Physiology.3rd. Ed. Sunderland; Sinauer Assoc. Pp.17-34

[33]. Thirumaran, G. and P. Anantharaman. 2009. Daily Growth Rate of FieldFarming Seaweed 
Seaweed Kappaphycus alvarezii (Doty) Doty ex P. Silva in Vellar Estuary. World Journal ofFish and Marine Sciences 1 (3); 144-153. Annamalai University

[34]. Van Oorschoot, J.L.P. 1955. Conversion of Light Energy in Algal Culture. H Veen man \&Zonen - Wageningen. 277 p.

[35]. Walsh, K., G. J. Jones. and R. H. Dunstan. 1997. Growth and metabolism In: PhytochemistryVolume 44, Issue 5, March 1997, Pages 817-82

[36]. Ying Yang, 2013. Effects of Temperature, Light Intensity and Quality, Carbon Dioxide, and Culture Medium Nutrients on Growth and Lipid Production of Ettliaoleo abundans. A Dissertation. Worcester Polythechnic Institute. 151p.

[37]. Xu, Y., I. M.Ibrahim,P. J.Harvey. 2016. The Influence of Photoperiod and Light Intensity on the Growth and Photosynthesis of Dunaliellasalina (Chlorophyta) .CCAP 19/30. Plant Physiology and Biochemistry106(2016)305-315

\section{Cite this article as :}

Rajuddin Syamsuddin, Rustam, Abustang, Idil Fitra, "Carotenoid Content and Weight Gain of Caulerpa racemosa (Chlorophyta, Caulerpaceae) at Several Light Intensities ", International Journal of Scientific Research in Science and Technology (IJSRST), Online ISSN : 2395-602X, Print ISSN : 2395-6011, Volume 6 Issue 2, pp. 436-444, March-April 2019.

Available at doi :

https://doi.org/10.32628/IJSRST196252

Journal URL : http://ijsrst.com/IJSRST196252 